\title{
GENETIC DIVERSITY OF ECHINOCOCCUS MULTILOCULARIS CESTODES IN EUROPE AS DETERMINED BY MITOCHONDRIAL AND NUCLEAR SEQUENCES
}

\author{
Šnábel Viliam ${ }^{1}$, Sréter Tamás ${ }^{2}$, Gottstein Bruno ${ }^{3}$, \\ Gawor Jakub $^{4}$, Romig Thomas ${ }^{5}$, Miterpáková Martina ${ }^{1}$
}

\begin{abstract}
Alveolar echinococcosis caused by metacestode stage of the tapeworm Echinococcus multilocularis is considered as one of the most pathogenic zoonoses in temperate and arctic regions. To more thoroughly ascertain genetic diversity in E. multilocularis tapeworms from Europe and to indicate transmission patterns of parasite, 25 isolates from a contiguous territory of eight European countries were subjected to sequencing of mitochondrial and nuclear DNA. A total of 2715 nucleotide sequences in nad1, $\operatorname{cox} 1, \operatorname{rrnS}$, atp 6 and actII genes were screened in the current study. Whereas in 24 isolates profiles belonging to a previously described European clade were identified, the interesting feature was related to the detection of the form being close to North American strain N1 (that appeared to have lower zoonotic potential) in Austrian patient. The known occurrence of this variant has thus extended from the St. Lawrence Island in the Bering Sea and Russian isolates in Yakutia to central Europe. The finding indicates that N1 genotype has not only circumpolar transBeringian distribution, but during glacial events in Pleistocene a more southerly fox dispersal has likely transmitted N1 into central Europe. Further distinguished genotype was confined to four isolates from southern Germany (mountain range of Swabian Jura) and had five substitutions compared to the main European form. One Latvian isolate had two mutations in cox1, one of which was identical to German isolates from Feldstetten. Single nucleotide polymorphisms were detected in single isolates from Slovakia, Hungary and France in cox 1 and actII genes. Lower genetic diversity detected in the examined isolates in more peripheral zones of its European distribution has supported Knapp's model (2009) suggesting that parasite focus in Europe is governed by "mainland-island" transmission where ancestral foci supply hitherto non-endemic areas by dispersal generated by fox mobility and migration.
\end{abstract}

\footnotetext{
${ }^{1}$ Institute of Parasitology, Slovak Academy of Sciences, 04001 Košice, Slovakia, snabel@saske.sk

${ }^{2}$ Natural Food Chain Safety Office, Laboratory for Parasitology, Fish \& Bee Diseases, Budapest, Hungary

${ }^{3}$ Institute of Parasitology, University of Bern, Bern, Switzerland

${ }^{4}$ Witold Stefański Institute of Parasitology, Polish Academy of Sciences, Warsaw, Poland

${ }^{5}$ University of Hohenheim, Department of Parasitology, Stuttgart, Germany
} 


\section{Аннотация}

Альвеолярный эхинококкоз, вызванный метацестодной стадией ленточного червя Echinococcus multilocularis, считается одним из наиболее патогенных зоонозов в умеренных и арктических регионах. Для более тщательного определения генетического разнообразия у ленточных червей E. multilocularis из Европы и для выявления характера передачи паразита 25 изолятов с прилегающей территории восьми европейских стран подвергали секвенированию митохондриальной и ядерной ДНК. В текущем исследовании было проведено скрининг в общей сложности 2715 нуклеотидных последовательностей в генах nad1, cox 1, rrnS, atp6 и actII. Принимая во внимание, что в 24 изолятах были определены профили, принадлежащие ранее описанной европейской кладе, интересная особенность анализа была связана с обнаружением формы, близкой к североамериканскому штамму N1 (который, по-видимому, имел более низкий зоонотический потенциал) у австрийского пациента. Таким образом, известное распространение этого варианта распространилось от острова Святого Лаврентия в Беринговом море и русских изолятов в Якутии до центральной Европы. Полученные данные указывают на то, что генотип N1 имеет не только циркумполярное трансберингианское распространение, но и во время ледниковых событий в плейстоцене более южное распространение лисы, вероятно, передало N1 в центральную Европу. Исторически сложилось, что формирование Берингова сухопутного моста («Берингии») в течение нескольких периодов плейстоцена, который сформировал убежище для распространения евразийских изолятов в Северную Америку и наоборот, служил важным регионом для диверсификации и развития E. multilocularis. Далее выделенный генотип был ограничен четырьмя изолятами из южной Германии (горная цепь Швабской Юры) и имел пять замен по сравнению с основной европейской формой. Один латышский изолят имел две мутации в cox 1, одна из которых была идентична немецким изолятам из Feldstetten. Однонуклеотидные полиморфизмы были обнаружены в единичных изолятах из Словакии, Венгрии и Франции в генах coxl и actII. Более низкое генетическое разнообразие, обнаруженное в исследованных изолятах в более периферийных зонах его европейского распространения, поддерживает модель Кнаппа (2009), предполагающую, что фокус паразитов в Европе регулируется передачей «материк-остров», где наследственные очаги снабжают до настоящего времени неэндемичные районы рассеяние, порожденное подвижностью лис и миграцией.

Keywords: Echinococcus multilocularis, genotype, sequences, Pleistocene, Beringia.

Introduction. Alveolar echinococcosis is of increasing public health concern in Europe, with high fatality rates and poor prognosis if managed incorrectly. In urban areas of Europe, the parasite is transmitted principally in red foxes, with human exposures mediated through companion animals. According to the latest records, the known range of $E$. multilocularis has markedly ex-

15-17 мая 2019 года, Москва 
tended across Europe and it is assumed to be currently distributed over the most of its territory. Recent evidence supports northward and southeastern expansions from a core endemic area in south-central Europe as documented by findings from Poland, Baltic countries, Slovakia, Hungary, Romania (summarized by Davidson et al., 2012; Oksanen et al., 2016). Prevalence trends of AE in humans appear to follow the surge in parasite abundance in wildlife coinciding with dramatic increases of fox population that began since 1990's (Mackenstedt et al., 2015). Molecular analyses of E. multilocularis have revealed a number of strains which can be strictly grouped into Asian, Mongolian, European and North American strains (Nakao et al., 2009; Ito et al., 2010). To more thoroughly examine the genetic variability and to indicate transmission patterns in E. multilocularis from Europe, isolates from a contiguous territory of eight European countries were subjected to analyses of mitochondrial and nuclear DNA sequences.

Materials and methods. Nucleotide composition of 25 E. multilocularis isolates collected from 8 European countries (Poland, Slovakia, Germany, Latvia, Hungary, Austria, Swizerland, France) and 18 capturing sites were examined. Samples were collected from six intermediate host species and red fox definitive host. After DNA isolation, four mitochondrial gene fragments (cox1, nad1, rrnS, atp6) and one nuclear gene (actII) were amplified. PCR was conducted under following conditions: an initial denaturation step at $94^{\circ} \mathrm{C}$ for $3 \mathrm{~min}$, followed by 30 cycles of $96^{\circ} \mathrm{C}$ for $30 \mathrm{sec}$, $56^{\circ} \mathrm{C}$ for $30 \mathrm{sec}, 72^{\circ} \mathrm{C}$ for $1 \mathrm{~min}$, final extension step $72^{\circ} \mathrm{C}$ for $7 \mathrm{~min}$, except for actII with the shorter extension time to $50 \mathrm{sec}$ to increase the stringency of amplification. Amplicons were then purified using a Nucleospin Extract II kit (Macherey Nagel, Düren, Germany) and directly sequenced using the BigDye Terminator Cycle Sequencing Kit (Applied Biosystems). The branching pattern was generated by MEGA7 software (Kumar et al., 2016) using the neighbor-joining (N-J) method.

Results. A total of 2715 nucleotide sequences in five gene targets were examined for every isolate ( $\mathrm{nad} 1-589 \mathrm{bp}$, cox $1-789 \mathrm{bp}, \mathrm{rrnS}-362 \mathrm{bp}$, atp $6-516 \mathrm{bp}$, actII $-459 \mathrm{bp})$. Altogether seven genotypes were detected in examined European sample. The most distinct profile possessed the human isolate originated from Austria, displaying 1-4 mutations in cox1, nad1, atp6, actII compared to remaining European isolates. Interestingly, all 4 nucleotide substitutions in cox1 were identical to reference isolates from North America (N1, N2) described in Nakao et al. (2009), and 2 of these sites were corresponding to samples belonging to Asian clade in the above study. This isolate from Austrian patient that matched most closely the N1 genotype structure was the only older isolate in the analyzed sample, obtained 
upon hepatic surgery in 1981 and subsequently maintained upon serial passage into gerbils and mice, with DNA isolated in 2003 (obtained from the Institut für Parasitologie, Universität Bern). There were no indications that the patient had ever been America or any other non-European remote areas where he could have got infected (B. Gottstein, personal communication). Beyond the North American continent, the N1 strain was before found in St. Lawrence Island (west of mainland Alaska), Svalbard archipelago (Norway), and in northeast and west Yakutia in Russia (Nakao et al., 2009; Knapp et al., 2012; Konyaev et al., 2013), thus globally predominating in northern territories. Based on observations in regions with high prevalence in definitive hosts yet low incidence of human AE it is presumed that the N1 genotype has lower zoonotic potential and pathogenicity (Davidson et al., 2016). Our finding of N1 pattern in Austria is the easternmost record of this variant within the Eurasian continent.

Four isolates from the Feldstetten locality in southern Germany (mountain range of Swabian Jura) exhibited genotype with five mutations compared to the main European form - one exchange in cox 1, and two exchanges in both nad 1 and atp6. One of these subsitutions in cox 1 was previously found also in France (E3 isolate) by Nakao et al. (2009). Remaining 6 German isolates had sequences fully identical to major European variant. One Latvian isolate displayed two nucleotide substitutions in cox 1, one of which was identical to German isolates from Feldstetten. In addition, single samples of Slovak and Hungarian isolates had one specific mutation in the cox 1 gene in different sites. In the actII gene, one French isolate from Jura department and the above Austrian isolate displayed one nucleotide substitution located in different positions. In dendrogram constructed from concatenated sequences, three major clades in European analyzed sample were established, first clade forming by Austrian isolate, second by German isolates from Feldstetten and third main clade consisted remaining European samples.

A degree of genetic diversity in a sample collected from historically documented core endemic region in Europe (Austria, France, Germany, Switzerland) that consisted of 16 isolates and a sample of 8 isolates from region where parasite was presumed to be established during northward expansion over the last two decades (Slovakia, Poland, Hungary. Latvia) was assessed. Although four genetic variants were detected in both zones, a significantly greater average nucleotide diversity $(\mathrm{P}<0.01)$ was detected in the core area $(\mathrm{pi}=0.001243)$ than in the region where parasite was identified recently $(\mathrm{pi}=0.000409)$. 
Conclusions. The North American genotype N1 detected in Austria indicates likely represents an ancestral form of E. multilocularis from glacial refugia maintaning in the historical endemic zone of Europe. It is hypothesized that E. multilocularis had extended into Europe in the Late Pleistocene Epoch $(130,000-10,000$ years ago) through the migration of foxes. Historically, the formation of the Bering land bridge ("Beringia") during several periods of the Pleistocene, which formed an refugium for expansion of the Eurasian isolates to North America and vice versa, has served as an important region for the diversification and evolution of E. multilocularis. Further distinguished genotype in the current study was found in a restricted territory of southern Germany in four isolates from water vole and its circulation in the broader area was later confirmed by detecting this pattern in three isolates from red fox by Schroer et al. (2010) in close territory.

Acknowledgements. The study was supported by the Scientific Grant Agency VEGA (project No. 2/0162/17).

\section{References}

1. Knapp, J., Bart, J.M., Giraudoux, P., Glowatzki, M.L. et al. (2009): Genetic Diversity of the Cestode Echinococcus multilocularis in Red Foxes at a Continental Scale in Europe. In PLoS Negl. Trop. Dis., 3(6): e452.

2. Knapp, J., Staebler, S., Bart, J.M., Stien, A., Yoccoz, N.G., Drögemüller, C., Gottstein, B., Deplazes, P. (2012): Echinococcus multilocularis in Svalbard, Norway: microsatellite genotyping to investigate the origin of a highly focal contamination. Infect. Genet. Evol., 1270-1274.

3. Konyaev, S.V., Yanagida, T., Nakao, M., Ingovatova, G.M. et al. (2013): Genetic diversity of Echinococcus spp. in Russia. In Parasitology 140(13): 1637-1647.

4. Nakao, M., Xiao, N., Okamoto, M., Yanagida, T., Sako, Y., Ito, A. (2009): Geographic pattern of genetic variation in the fox tapeworm Echinococcus multilocularis. Parasitol. Int., 58(4): 384-389 